\title{
PENDAMPINGAN PEMBUKUAN SEDERHANA PADA UMKM MITRA LEMBAGA PENGEMBANGAN BISNIS PAMA BENUA ETAM (LPB PABANET) SANGATTA
}

\author{
Muhamad Yazid Bustomi ${ }^{1}$, Rusmiyati ${ }^{1}$, Joko Suryanto ${ }^{1}$, dan Hendra ${ }^{2}$ \\ ${ }^{1}$ Sekolah Tinggi Pertanian Kutai Timur \\ ${ }^{2}$ Lembaga Pengembangan Bisnis Pama Benua Etam \\ E-mail: myazid.bustomi@ stiperkutim.ac.id
}

\begin{abstract}
ABSTRAK
Usaha mikro, kecil, dan menengah yang banyak tumbuh di masyarakat Indonesia dapat diartikan sebagai suatu usaha yang dapat menggerakkan roda perokonomian melalui penciptaan produk dan penyerapan tenaga kerja. Pelaku usaha harus dapat mengelola usahanya melalui pencatatan transaksi keuangan yang dibuktikan dengan adanya laporan keungan usaha sebagai salah satu bukti kineja UMKM. Kegiatan pendampingan ini bertujuan (1) memberikan pemahaman tentang pentingnya pelaku usaha (UMKM) untuk melakukan pembukuan atau pencatatan keuangan, (2) menjelaskan proses pencatatan transaksi dan langkah-langkah dalam menyusun laporan keuangan. Kegiatan pengabdian ini dilakukan pada UMKM yang tergabung sebagai UMKM Mitra LPB Pabanet dalam bentuk penyuluhan dengan metode ceramah, diskusi, kemudian dilanjutkan dengan pendampingan langsung kepada UMKM sesuai dengan sektor usahanya. Para peserta UMKM Mitra dapat mengikuti kegiatan dengan baik terlihat dari antusias dan kemampuan dalam mengerjakan soal latihan yang diberikan terkait dengan contoh transaksi usaha, laporan keuangan, juga dapat menghitung harga pokok produksi. Pelaku usaha dapat memahami pentingnya laporan keuangan untuk rencana investasi selanjutnya.
\end{abstract}

Kata Kunci: Laporan Keuangan, Pendampingan, Transaksi, UMKM.

\section{PENDAHULUAN}

Usaha mikro, kecil, dan menengah (UMKM) merupakan suatu usaha atau bisnis yang tahan banting, hal tersebut dibuktikan ketika krisis ekonomi yang terjadi di Indonesia pada era 98 yang berdampak signifikan terhadap kondisi ekonomi Indonesia secara global, namun tidak berdampak langsung terhadap para pelaku usaha mikro (Hapsari et al., 2017). Sementara, Zulfikar et al., (2019) menyatakan bahwa UMKM memiliki peranan yang cukup penting bagi perkembangan perekonomian suatu daerah. Untuk mendukung petumbuhan UMKM, Huda et al., (2018) menjelaskan bahwa pelaku UMKM harus mampu bersaing satu sama lain dengan membuat sesuatu yang unik berorientasi pasar dan konsumen.

Semakin berkembangnya usaha, menuntut para pelaku usaha mikro untuk berhubungan dengan pihak eksternal perusahaan. Pihak bank atau lembaga 
keuangan sebagai pihak eksternal biasanya akan mensyaratkan laporan keuangan untuk menilai kelayakan kredit dari usaha tersebut, sehingga pengelolaan modal kerja dapat diketahui secara jelas.

Ling (2013) menyatakan bahwa keuangan suatu usaha dikelola oleh pemilik dimana aktivitas keuangan dilakukan dengan sistem pembukuan secara manual dengan menggunakan pencatatan akuntansi, mengurus nota penjulan dan nota pembelian. Ernawati et al., (2016) menyebutkan bahwa laporan keuangan menjadi salah satu komponen yang mutlak harus dimiliki oleh usaha mikro jika mereka ingin mengembangkan usaha dengan mengajukan modal kepada kreditur yang dalam hal ini adalah pihak perbankan.

Salah satu kendala yang sering dihadapi oleh para pelaku usaha ini adalah masalah penyusunan laporan keuangan, hal ini bisa dimaklumi karena tidak semua pelaku bisnis usaha mikro memiliki latar belakang akuntansi, sedangkan jika harus memperkerjakan seorang akuntan masih belum memungkinkan secara finansial. Hal tersebut tentu saja akan membuat setiap pelaku usaha mikro kesulitan dalam menyusun laporan keungan mereka.
Usaha mikro, kecil yang berada di Kecamatan Sangatta Utara dan Kecamatan Sangatta Selatan, Kabupaten Kutai Timur merupakan usaha yang tumbuh secara tradisional, juga merupakan usaha keluarga yang turun temurun. Lembaga Pengembangan Bisnis Pama Benua Etam (LPB Pabanet) merupakan salah satu lembaga dari yayasan dharma bakti astra (YDBA) yang tersebar di beberapa wilayah di Indonesia. LPB Pabanet melakukan pembinaaan dan bimbingan kepada pelaku usaha UMKM dalam rangka membantu pertumbuhan dan perkembangan UMKM khususnya di wilayah Kabupaten Kutai Timur.

Bismala (2016) menjelaskan UMKM memerlukan pendampingan dari berbagai institusi untuk dapat mengaplikasikan ilmu dan pengetahuan baik dari pemerintah, instansi, maupun lembaga pendidikan. Sementara Hapsari et al., (2017) menyebutkan bahwa keterbatasan kualitas SDM pada usaha kecil tersebut baik dari segi pendidikan maupun pengetahuan dan keterampilannya menyebabkan usaha sulit berkembang. Oleh sebab itu, perlu adanya pengetahuan terkait manajemen pengelolaan usaha khususnya pengelolaan keuangan, agar usaha 
tersebut dapat berkembang dengan optimal.

Tujuan kegiatan pengabdian kepada masyarakat dengan melakukan pendampingan pembukuan sederhana untuk UMKM Mitra yaitu (1) memberikan pemahaman tentang pentingnya pelaku usaha dalam hal ini UMKM melakukan pembukuan atau pencatatan keuangan terhadap usaha yang dijalankan, (2) menjelaskan proses pencatatan transaksi dan langkahlangkah dalam menyusun laporan keuangan. Pemahaman tersebut sangat diperlukan dalam rangka keberlanjutan dan pengembangkan usaha melalui investasi usaha kedepan sebagaimana asas dan tujuan UMKM yang tertuang dalam Undang-Undang Nomor 20 Tahun 2008.

\section{METODE PELAKSANAAN}

Kegiatan pendampingan pembukuan sederhana dilakukan untuk UMKM yang tergabung sebagai anggota atau mitra dari LPB Pabanet yang berada di wilayah Kecamatan Sangatta Utara dan Sangatta Selatan Kabupaten Kutai Timur. Kegiatan ini dilakukan melalui beberapa tahapan. Tahap pertama yaitu kegiatan penyampaian materi bersama yang diikuti semua anggota UMKM Mitra LPB Pabanet.
Penyampaian materi dilakukan dengan metode presentasi dan diskusi melalui bantuan proyektor, LCD, papan tulis, serta di akhir kegiatan peserta diminta untk mengerjakan soal-soal latihan terkait dengan transaksi-transaksi keuangan, permasalahan pembukuan atau laporan keuangan. Tahap kedua yaitu melakukan melakukan pendampingan langsung dengan berkunjung ke salah satu rumah pemilik UMKM. Kegiatan kunjungan atau pendampingan dilakukan berdasarkan sektor usaha UMKM melalui penjelasan yang lebih detail dan berfokus pada sektor usaha tertentu sehingga para pemilik UMKM menjadi lebih mudah memahami pembukuan sederhana dan pengelolaan keuangan.

\section{HASIL DAN PEMBAHASAN}

Fokus utama kegiatan ini adalah memberikan wawasan dan gambaran kepada anggota UMKM Mitra LPB Pabanet akan pentingnya pencatatan keuangan terhadap usaha yang dijalankan. Berdasarkan data yang dihimpun oleh LPB Pabanet terdapat sekitar 115 UMKM di Kecamatan Sangatta Utara dan 20 UMKM di Kecamatan Sangatta Selatan yang tergabung sebagai anggota UMKM Mitra LPB Pabanet. Rincian anggota 
UMKM dapat dilihat pada tabel 1. di

bawah ini :

Tabel 1. Sebaran Sektor Usaha UMKM Mitra LPB

\begin{tabular}{|c|c|c|c|}
\hline $\begin{array}{l}\text { Sektor Usaha } \\
\text { UMKM }\end{array}$ & $\begin{array}{l}\text { Jumlah } \\
\text { Anggota }\end{array}$ & $\begin{array}{l}\text { Sebaran } \\
\text { Wilayah }\end{array}$ & Keterangan \\
\hline \multirow{2}{*}{$\begin{array}{l}\text { Perikanan Air } \\
\text { Tawar }\end{array}$} & 25 & $\begin{array}{l}\text { Sangatta } \\
\text { Utara }\end{array}$ & \multirow{2}{*}{$\begin{array}{l}\text { Pemijahan dan } \\
\text { Pembesaran } \\
\text { Ikan Nila, Ikan } \\
\text { Lele }\end{array}$} \\
\hline & 5 & $\begin{array}{l}\text { Sangatta } \\
\text { Selatan }\end{array}$ & \\
\hline \multirow{2}{*}{ Pertanian } & 36 & $\begin{array}{l}\text { Sangatta } \\
\text { Utara }\end{array}$ & \multirow{2}{*}{$\begin{array}{l}\text { Tanaman } \\
\text { Holtikultura }\end{array}$} \\
\hline & 3 & $\begin{array}{l}\text { Sangatta } \\
\text { Selatan }\end{array}$ & \\
\hline \multirow{2}{*}{ Peternakan } & 12 & $\begin{array}{l}\text { Sangatta } \\
\text { Utara }\end{array}$ & \multirow{2}{*}{$\begin{array}{l}\text { Sapi, Kelinci, } \\
\text { kambing }\end{array}$} \\
\hline & 7 & $\begin{array}{l}\text { Sangatta } \\
\text { Selatan }\end{array}$ & \\
\hline \multirow[b]{2}{*}{ Home Industry } & 42 & $\begin{array}{l}\text { Sangatta } \\
\text { Utara }\end{array}$ & \multirow{2}{*}{$\begin{array}{l}\text { Makanan } \\
\text { Kemasan, } \\
\text { Kuliner, } \\
\text { Minuman } \\
\text { Ekstrak }\end{array}$} \\
\hline & 5 & $\begin{array}{l}\text { Sangatta } \\
\text { Selatan }\end{array}$ & \\
\hline
\end{tabular}

Kegiatan pertama yaitu penyampaian materi bersama dilakukan pada salah satu tempat UMKM yaitu Pemancingan Paino bertempat di Jl. Kabo Jaya Desa Swarga Bara Kecamatan Sangatta Utara dengan materi terkait pentingnya pembukuan dan pencatatan keuangan bagi usaha UMKM serta penjelasan tentang bentuk buku-buku transaksi untuk UMKM.

Materi yang disampaikan kepada peserta terdiri dari pengantar terkait kinerja UMKM yang terlihat dari laporan keuangan, yang mana laporan tersebut dapat berfungsi sebagai gambaran keadaan keuangan dan kemudahan untuk mengatasi masalah permodalan yang sering dihadapi oleh UMKM. Peserta diingatkan untuk memisahkan antara uang usaha dengan uang pribadi tujuannya agar dapat diketahui tingkat keuntungan usaha dan besarnya pengeluaran dalam satu periode perhitungan.

Selain itu, disampaikan juga terkait buku-buku transaksi usaha yang mana menurut Alteza (2014) pelaku UMKM perlu mempersiapkan buku untuk mencatat transaksi agar tertib administrasi dalam keuangannya. 
Beberapa buku yang harus dipersiapkan yaitu buku kas, buku pembelian, buku penjualan, buku piutang, dan buku hutang ditambah lagi buku persedian barang dan buku biaya. Tujuan dalam memperkenalkan bentuk buku-buku transaksi kepada UMKM adalah agar mereka dapat membedakan transaksitransaksi yang terjadi dan ditempatkan pada buku yang sesuai, namun kami lebih menekankan kepada UMKM agar wajib memiliki buku kas dalam setiap usahanya.

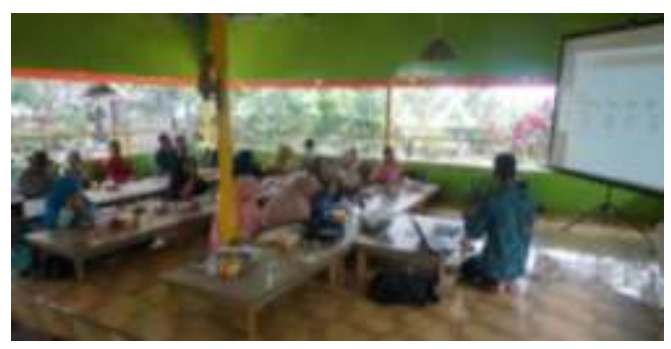

Gambar 1. Penyampaian Materi Pembukuan Sederhana

Peserta UMKM juga diajarkan cara membuat laporan keuangan sebagai hasil akhir dari suatu proses pembukuan dalam satu periode. Pada umumnya laporan keuangan yang disusun oleh UMKM dapat berupa laporan laba/rugi dan laporan posisi keuangan (neraca). Laporan keuangan dapat berperan sebagai pertanggungjawaban dan alat penilaian kinerja suatu usaha. Laporan keuangan bermanfaat untuk mengetahui posisi keuangan UMKM, mengetahui laba atau rugi usaha selama periode usaha, dan dapat memberikan informasi kepada pihak luar perusahaan. Selain itu, peserta juga dibekali cara menghitung harga pokok produksi (HPP) agar pelaku UMKM memiliki dasar atau pengetahuan dalam menentuakan harga jual produk.

Untuk memperdalam pemahaman UMKM dalam pembukuan sederhana dilakukan pendampingan langsung dan praktek dalam melalukan pencatatan transaski keuangan atas usaha UMKM sesuai dengan sektor usaha masingmasing. Kegiatan pendampingan pertama dilakukan pada UMKM sektor home industry yang berlokasi di $\mathrm{Jl}$. Abdul Wahab Syahrani Sangatta Utara. Sektor ini memiliki jumlah anggata yang lebih banyak daripada anggota yang lain, dan sebagian besar UMKM sudah memahami dan mulai menerapkan pembukuan dalam usaha mereka masing-masing, hal tersebut dapat terlihat dari antusias anggota sektor home industry dalam mengikuti kegiatan pendampingan sebagaimana terlihat pada gambar 2. di bawah ini. 


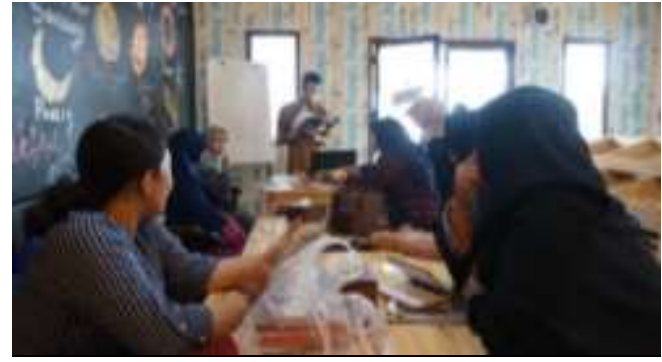

Gambar 2. Pendampingan UMKM Sektor Home Industry

Usaha di sektor home industry UMKM Mitra LPB Pabanet terdiri dari usaha makanan kemasan, kuliner, dan minuman ekstrak dari kunyit, jahe dan rempah lainnya. Produk dari hasil produksi UMKM selain dijual oleh masing-masing UMKM, pihak LPB juga menyiapkan lapak untuk penjualan produk-produk UMKM Mitra yang diberi nama OKUSA (olahan kuliner Sangatta).

Kegiatan pendampingan kedua pada UMKM sektor perikanan air tawar yang dilakukan di salah satu tempat usaha UMKM yaitu di Pemancingan Pasundan milik Bapak Arianto yang terletak di Jl. Soekarno Hata Sangatta Utara. Usaha pada sektor perikanan terdiri dari pemijahan, pembesaran ikan lele dan ikan nila. Selain itu juga ada usaha produksi pakan ikan. Peserta UMKM dapat mengikuti penyampaian terkait dengan bentuk-bentuk buku transaksi, dan lebih ditekankan pada buku kas yang wajib dimiliki oleh
UMKM karena terkait dengan kondisi keuangan usaha. Pada gambar 3. di bawah ini merupakan gambaran kegiatan pendampingan yang telah dilakukan.

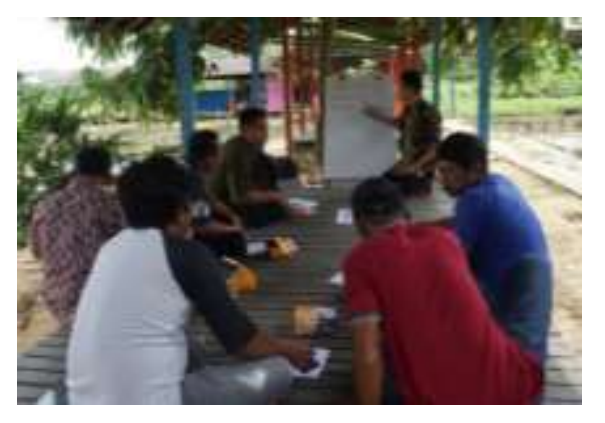

Gambar 3. Pendampingan UMKM Sektor Perikanan Air Tawar

Kegiatan pendampingan yang terakhir dilakukan pada UMKM sektor peternakan bertempat di Jl. Jendral Sudirman Sangatta Utara yaitu usaha peternakan kelinci milik salah satu anggota UMKM Mitra. Kegiatan tersebut dapat diikuti dengan baik oleh anggota UMKM Mitra melalui diskusi dan tanya jawab terkait permasalahan dalam pencatatan keuangan untuk sektor peternakan. Sektor peternakan dalam menghitung keuntungan memerlukan waktu periode pencatatan yang relatif lebih lama dibanding sektor lainnya, karena proses produksi pada sektor peternakan membutuhkan waktu yang cukup lama, oleh karena itu peserta juga dikenalkan terkait biaya investasi dan operasional usaha yang biasanya banyak dikeluarkan di awal-awal berdirinya usaha. Berikut ini gambar terkait 
kegiatan pendampingan pada sektor peternakan.

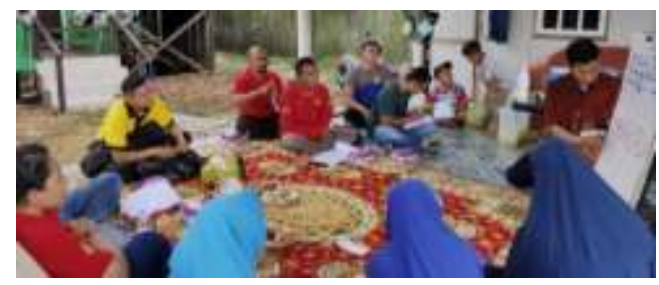

Gambar 4. Pendampingan UMKM

Sektor Peternakan

Kegiatan pendampingan pada sektor pertanian tidak dilakukan karena keterbatasan pengabdi. Secara umum kegiatan pendampingan dapat diikuti semua peserta yang hadir, dan juga peserta UMKM dibekali buku kas sebagai contoh buku transaksi usaha dengan harapan peserta dapat menerapkan ilmu yang didapat selama kegiatan pendampingan.

\section{KESIMPULAN}

Kegiatan pengabdian kepada masyarakat melalui pendampingan pembukuan sederhana berjalan dengan baik dan dapat diterima oleh anggota UMKM. Peserta UMKM dapat memahami pentingnya pencataan keuangan dalam setiap transaksi keuangan yang terjadi pada usahanya, hal tersebut terlihat dari antusias mereka dalam mempersiapkan buku-buka transaksi pada administrasi usaha. Selain itu, para pemilik UMKM dapat memahami format dan proses pembuat laporan keuangan yang terdiri dari laproran rugi/laba dan laporan posisi keuangan (neraca), serta cara menghitung harga pokok produksi yang terlihat dari kemampuan peserta dalam mengerjakan soal-soal latihan yang diberikan.

Saran yang disampaikan yaitu agar usaha dapat berjalan dengan baik dan terus berkembang, para pemilik UMKM diharapkan untuk sungguh-sungguh dalam melakukan pencatatan keuangan terhadap transaksi yang terjadi agar mereka dapat diketahui keuntungan bersih (laba) dalam suatu periode pencatatan akuntansi sehingga dapat melakukan evaluasi dan rencana investasi selanjutnya.

\section{UCAPAN TERIMA KASIH}

Penulis mengucapkan terima kasih kepada Lembaga Pengembangan Bisnis Pama Benua Etam (LPB Pabanet) atas dukungan, bantuan serta telah memfasilitasi dalam kegiatan ini juga sebagai bentuk kerjasama antara LPB Pabanet dengan Sekolah Tinggi Pertanian Kutai Timur.

\section{DAFTAR PUSTAKA}

Alteza, M. (2014). Akuntansi Mudah dan Sederhana Untuk Usaha Kecil dan Menengah (UKM). In PPM 
Fakultas Ekonomi Universitas Negeri Yogyakarta. Retrieved from http://staffnew.uny.ac.id/upload/13 2303686/pengabdian/PPM_Simple Accounting Bagi UKM Emping Ketela di Desa Ringinharjo Bantul.pdf

Bismala, L. (2016). Model Manajemen Usaha Mikro Kecil dan Menengah (UMKM) untuk Meningkatkan Efektivitas Usaha Kecil Menengah. Jurnal Enterpreuner Dan Enterpreneurship, 5(1), 19-25.

Ernawati, S., Asyikin, J., \& Sari, O. (2016). Penerapan Sistem Akuntansi Dasar pada Usaha Kecil Menengah di Kota Banjarmasin. Jurnal Penelitian Ilmu Ekonomi WIGA, 6(2), 81-91.

Hapsari, D. P., Andari, \& Nahdiatul, A. H. (2017). Model Pembukuan Sederhana Bagi Usaha Mikro di Kecamatan Kramatwatu Kabupaten Serang. Jurnal Akuntansi, 4(2), 3647.

Huda, N., Nazwirman, N., \& Hulmansyah, H. (2018). Pembinaan
Organisasi Kelompok Usaha Mandiri Masyarakat (KUMM) Berbasis Akuntabilitas dan Islami. Jurnal Pengabdian AlIkhlas Universitas Islam Kalimantan Muhammad Arsyad Al Banjary, 2(2).

Ling, A. (2013). Pengelolaan Dan Pengembangan Usaha Pada Usaha Mikro Kecil Menengah (Studi Deskriptif Pada Rumah Makan Palem Asri Surabaya). Agora, 1(1).

Undang-Undang Republik Indonesia Nomor 20 Tahun 2008 terkait Usaha Mikro, Kecil, dan Menengah.

Zulfikar, R., Mayvita, P. A., \& Purboyo, P. (2019). Adopsi Teknik Penyusunan Business Plan Model Canvas Untuk Perencanaan Bisnis Umkm Kuliner Jalanan Di Kawasan Gatot Subroto Banjarmasin. Jurnal Pengabdian Al-Ikhlas Universitas Islam Kalimantan Muhammad Arsyad Al Banjary, 4(2). 